\title{
MENINGKATKAN HASIL BELAJAR MELALUI PENERAPAN MEDIA WAYANG PADA MATA PELAJARAN BAHASA INDONESIA KELAS V SEKOLAH DASAR ISLAM TERPADU AD-DHUHA
}

\author{
Rina Juliana \\ Institut Agama Islam Yasni Bungo \\ Email: rinajulianaazkiya@gmail.com
}

\section{Dedi Yuisman}

Institut Agama Islam Yasni Bungo

Email: dediyuisman@gmail.com

\section{Mualimin}

Institut Agama Islam Yasni Bungo

Email: mualimin1213@gmail.com

\section{Fitria Carli Wiseza}

Institut Agama Islam Yasni Bungo

Email: fitriawiseza@gmail.com

\section{Muhammad Ridho}

Institut Agama Islam Yasni Bungo

Email:muhammadridhoiaiyasni@gmail.com

\begin{abstract}
Abstrack
This research aims to improve the learning outcomes of Indonesian students in grade $\mathrm{V}$ of the Ad-dhuha Integrated Islamic Elementary School, Purwasari hamlet. which is motivated by low student learning outcomes and low student participation in learning Indonesian. This is because the learning process has not used a variety of learning media. This type of research is a classroom action research conducted collaboratively between teachers and researchers. This research was conducted in 2 cycles using the research design of Kemmis and Mc. Taggart which consists of four stages, namely planning, observing action, reflection and re-planning. The subjects of this study were the fifth grade students of the Islamic Elementary School Ad-dhuha Purwasari, totaling 23 students. The data was collected by means of observation, interviews, tests and documentation. The indicators of success in this study are knowledge, image, understanding, explaining, summarizing, implementing, describing, planning, assessing. The results of learning observations by applying wayang media have met the indicators of research success, namely $70 \%$ on each indicator of learning outcomes. The percentage, student learning outcomes in pre-cycle was $43.47 \%$, in cycle I showed $47.82 \%$, and in cycle II it reached $82,60 \%$ so that it already has a good
\end{abstract}

Nur El-Islam, Volume 8, Nomor 1, April 2021 
success rate .Based on the hypothesis of the action taken, the use of wayang media can improve the learning outcomes of Class $\mathrm{V}$ students in Indonesian Language subjects at the Ad-Dhuha Integrated Islamic Elementary School.

Keywords: Wayang Media, Learning Outcomes, Indonesian Language.

\section{Abstrak}

Penelitian ini bertujuan untuk meningkatkan hasil belajar Bahasa Indonesia siswa kelas V Sekolah Dasar Islam Terpadu Ad-dhuha dusun Purwasari yang dilatar belakangi oleh rendahnya hasil belajar belajar siswa dan rendahnya partisipasi siswa dalam pembelajaran Bahasa Indonesia. Hal itu dikarenakan dalam proses pembelajaran belum menggunakan media pembelajaran yang bervariasi. Jenis penelitian ini adalah penelitian tindakan kelas yang dilaksanakan secara kolaboratif antara guru dengan peneliti. Penelitian ini dilaksanakan dalam 2 siklus dengan menggunakan desain penelitian Kemmis and Mc. Taggart yang terdiri dari empat tahapan yaitu perencanaan, tindakan pengamatan, refleksi dan perencanaan ulang. Subjek penelitian ini adalah siswa kelas V Sekolah Dasar Islam Terpadu Ad-dhuha dusun Purwasari, yang berjumlah 23 siswa. Pengumpulan data dilakukan dengan cara observasi, wawancara, tes dan dokumentasi. Indikator keberhasilan dalam penelitian ini adalah pengetahuan, imgatan, pemahaman, menjelaskan, meringkas, menerapkan, menguraikan, merencanakan, menilai. Hasil pengamatan pembelajaran dengan menerapkan media pembelajaran berupa media wayang telah memenuhi indicator keberhasilan penelitian yaitu $70 \%$ pada masing-masing indicator hasil belajar.persentase hasil belajar siswa pada prasiklus adalah 43,47\%, pada siklus I menunjukkan 47,82\%, dan pada siklus II mencapai 82,60\%, sehingga sudah memiliki tingkat keberhasilan dengan predikat baik. Berdasarkan hipotesis tindakan yang dilakukan maka penggunaan media wayang dapat meningkatkan hasil belajar siswa Kelas V pada mata pelajaran Bahasa Indonesia di Sekolah Dasar Islam Terpadu Addhuha.

Kata Kunci: Media Wayang, Hasil Belajar, Bahasa Indonesia

\section{PENDAHULUAN}

\section{A. Latar Belakang Masalah}

Pembelajaran bahasa Indonesia di sekolah dasar (SD) secara umum bertujuan agar siswa memiliki kemampuan dan kecakapan dalam berkomunikasi dengan menggunakan bahasa Indonesia dengan baik dan benar, secara lisan maupun tertulis. Sementara secara khuhus tujuan pembelajaran bahasa Indonesia adalah (1) berkomunikasi secara efektif dan efisien sesuai etika yang berlaku, (2) menghargai dan bangga menggunakan bahasa Indonesia sebagai bahasa persatuan dan bahasa bangsa, (3) memahami bahasa Indonesia 
dan menggunakannya dengan tepat dan kreatif untuk berbagai tujuan, (4) menikmati dan memanfaatkan karya sastra untuk memperluas wawasan, memperluas budi pekerti, meningkatkan pengetahuan dan kemampuan berbahasa, (5) untuk meningkatkan kemampuan intelektual, serta kematangan emosional dan sosial, (6) menghargai dan membanggakan sastra Indonesia sebagai kazhanah budaya serta intelektual manusia Indonesia ${ }^{1}$. Sejalan dengan tujuan yang telah dijabarkan di atas maka siswa diharapkan memiliki kemampuan berbahasa, paling tidak berupa kemampuan untuk melakukan komunikasi yang dapat diterima oleh orang lain.

Melalui bahasa manusia dapat saling mengenal dan berhubungan satu sama lain. Dengan bahasa manusia juga dapat menyampaikan berbagai berita, pikiran, pendapat, peranan, keinginan, dan harapan ${ }^{2}$. Oleh karena itu, bahasa memiliki kedudukan dan fungsi yang sangat penting sehingga di perlukan pembinaan dan pengembangan. Salah satu cara dalam melaksanakan pembinaan dan pengembangan bahasa adalah melalui pembelajaran bahasa Indonesia yang di ajarkan dikelas. Jadi dapat disimpulkan definisi Bahasa Indonesia yaitu merupakan alat komunikasi yang digunakan oleh masyarakat Indonesia untuk keperluan sehari- hari, misalnya belajar, bekerjasama, dan berinteraksi.

Bahasa Indonesia mempunyai ragam lisan dan tulisan yang keduanya harus digunakan dalam situasi formal dan nonformal sehingga guru memperkenalkan bahasa Indonesia kepada siswa. Ruang lingkup pembelajaran bahasa Indonesia mencakup empat aspek keterampilan berbahasa, yaitu (1) menyimak, (2) berbicara, (3) membaca, (4) menulis ${ }^{3}$. Untuk itulah siswa diajarkan empat aspek keterampilan berbahasa yang diperlukan dalam berkomunikasi.

${ }^{1}$ Depdiknas, Permrndiknas No 22tahun 2006 Tentang Standar Isi. (Jakarta: Depdiknas, 2006), hal. 10.

2 Zainal Aqib DKK, Penelitian Tindakan Kelas SD/MI (Yogyakarta:Ar-Ruzz Media,2017), hal. 136.

${ }^{3}$ Depdiknas, Permrndiknas No 22tahun 2006 Tentang Standar Isi. (Jakarta: Depdiknas, 2006), hal. 23. 
Ketrampilan dalam aspek bahasa dapat dimulai dari ketrampilan menyimak. Menyimak (mendengarkan) merupakan salah satu aspek yang terpenting dalam kesuksesan bahasa. Untuk mengetahui isi yang sedang dibicarakan membutuhkan sebuah konsentrasi yang penuh agar kita dapat menyimak dengan baik dan mengetahui apa isinya. Tetapi untuk menumbuhkan konsentrasi penuh bukan pekerjaan yang mudah ${ }^{4}$.

Menyimak merupakan suatu proses kegiatan mendengarkan lambang-lambang lisan dengan penuh perhatian, pemahaman, apresiasi, serta interpretasi untuk memperoleh informasi, menangkap isi atau pesan, serta memahami makna komunikasi yang telah disampaikan sang pembicara melalui ujaran atau bahasa lisan. Mendengar bersifat pasif dan spontan, sedangkan menyimak bersifat aktif. Menyimak menyangkut proses interpretasi terhadap informasi yang datang. Jadi dalam menyimak diperlukan konsentrasi, perhatian yang sungguh-sungguh kesengajaan, pemahaman, dan kehati-hatian.

perlu ditingkatkan supaya tidak mempengaruhi proses memperoleh informasi dan komunikasi.

Sebagaimana dijelaskan juga dalam al-quran sebagai berikut :

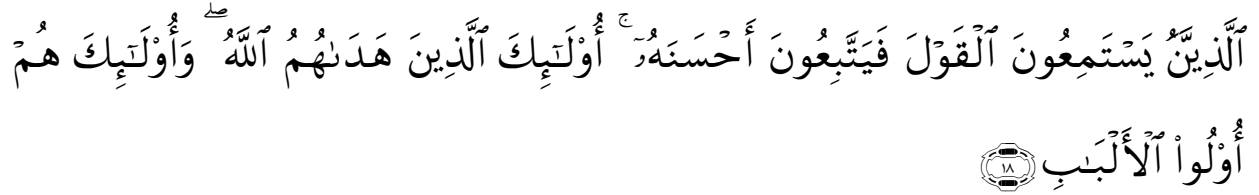

Artinya : "Yang mendengarkan Perkataan lalu mengikuti apa yang paling baik di antaranya. mereka Itulah orang-orang yang telah diberi Allah petunjuk dan mereka Itulah orang-orang yang mempunyai akal.” (Q.S Az-zumar:18)

${ }^{4}$ Widayati, Penggunaan Media Wayang Untuk Meningkatkan Keterampilan Menyimak Cerita Pendek,( BRILLIANT: Jurnal Riset dan Konseptual Volume 2 Nomor 1, 2017), hal. 44. 
Media merupakan wahana penyalur informasi belajar atau penyalur pesan. Berdasarkan uraian diatas dapat disimpulkan bahwa media merupakan suatu alat yang digunakan oleh seorang pendidik untuk mempermudah penyampaian materi kepada peserta didik sehingga akan tercapai tujuan pemelajaran yang diinginkan. ${ }^{5}$ Sedangkan wayang adalah benda tiruan dari bentuk manusia atau binatang. Media wayang merupakan sebuah media yang termasuk ke dalam jenis media visual yang berbentuk tiga dimensi, karena media ini dapat dilihat dan dipegang. Dalam pembelajaran bahasa Indonesia materi mengidentifikasi unsur cerita cara meragakan media ini guru bercerita dengan meragakan media wayang yang sesuai dengan ceritanya. ${ }^{6}$

Jadi dalam hal ini, guru dituntut memerankan tokoh dalam cerita. Alasan peneliti menggunakan media ini karena peneliti ingin membuat pembelajaran menjadi lebih menarik selain itu, medi ini dapat mempermudah siswa mengidentifikasi unsur cerita. Kelebihan media wayang ini lebih memperjelas pesan dan informasi sehingga mudah dipahami oleh siswa dan meningkatkan proses hasil pembelajaran. Dengan menggunakan media ini, tentunya apa yang disampaikan akan menjadi lebih menarik dan konsentrasi mengenai apa yang disampaikan oleh guru.

Kenyataan yang terjadi di Sd IT Ad- Dhuha, berdasarkan pengamatan yang dilakukan peneliti pada bulan februari 2020 tepatnya di kelas $\mathrm{V}$ pada saat proses terjadinya kegiatan belajar mengajar di kelas, bahwasanya pembelajaran bahasa Indonesia pada aspek menyimak (mendengaarkan) pada sebuah cerita yang di sampaikan oleh seorang guru banyak siswa yang kurang tertarik dalam menyimak sehingga saat dikasih soal untuk mengisi jawaban ditemukan dari 23 jumlah siswa hanya 9 siswa yang mencapai

${ }^{5}$ Djamarah dan Zain dalam Widayati, Penggunaan Media Wayang Untuk Meningkatkan Keterampilan Menyimak Cerita Pendek, (BRILLIANT: Jurnal Riset dan Konseptual Volume 2 Nomor 1, 2017), hal. 44.

${ }^{6}$ Daryanto dalam Widayati, Penggunaan Media Wayang Untuk Meningkatkan Keterampilan Menyimak Cerita Pendek, ( BRILLIANT: Jurnal Riset dan Konseptual Volume 2 Nomor 1, 2017), hal. 44. 
ketuntasan sedangkan 14 siswa belum mencapai ketuntasan, maka dapat dilihat lebih dari 60\% siswa banyak yang belum mencapai $\mathrm{kkm}$ yang telah ditentukan ini di buktikan dengan niliai ulangan harian siswa. ${ }^{7}$ Beberapa siswa lebih cenderung bercakap- cakap dengan teman sebangku, sebagian besar siswa gaduh atau ribut. Setelah guru selesai menyampaikan atau membacakan sebuah cerita tadi dan kemudian guru mengajukan beberapa pertanyaan kepada siswa, dan yang terjadi banyak siswa yang terdiam, bahkan beberapa siswa sibuk untuk membaca teks cerita kembali, dan ada pun beberapa siswa yang menjawab tetapi jawaban yang diberikan atau diungkapkan itu juga belum mencapai sasaran yang diingkan oleh guru. Maka dari itu tiga indikator hasil belajar yang ingin diteliti oleh peneliti yang terdapat dalam teori yang dikemukakan oleh Bloom, hasil belajar mencakup kemampuan kognitif, afektif, dan psikomotorik. Dan dalam penelitian ini peneliti memilih ranah kognitif yang memiliki beberapa indikator diantaranya adalah Knowledge (pengetahuan, ingatan), Comprehension (Pemahaman, menjelaskan, meringkas,contoh), Aplication (menerapkan), Analysis (menguraikan), Synthesis (mengorganisasikan, merencanakan, membentuk bangunan baru), Evaluation (menilai) ${ }^{8}$, dari keenam inikator di atas belum Nampak didalam kelas V Sd IT Ad- Dhuha.

Dari pelaksanaan pembelajaran tang terjadi di dalam kelas, bahwa peneliti melihat antusias belajar siswa itu lebih menyukai pembelajaran bercerita dengan menggunakan media pada materi cerita sehingga proses menyimak (mendengarkan) siswa akan lebih focus terhadap pembelajaran yang disampaikan. Tetapi kenyataannya yang terjadi pembelajaran dalam materi cerita selama ini yang di ajarkan oleh guru masih menerapkan pembelajaran yang sederhana yaitu dengan berceramah dan kurangnya kreatifitas seorang guru dalam menyampaikan meteri. Sehingga aktivitas pembelajaran yang masih bersifat konvensional ini belum mampu meningkatkan hasil

${ }^{7}$ Hasil Observasi pada bulan februari 2020

8 Agus Suprijono, Cooperatif Learning: Teori \& Aplikasi PAIKEM (Yogyakarta:Pustaka Pelajar,2013), cet.10, hal. 6. 
belajar siswa pada materi cerita rakyat kurang maksimal, maka akan terjadi kendala dalam mendapatkan nilai yang memuaskan.

Berdasarkan permasalahan di atas, harus diperlukan suatu bentuk pembelajaran yang mampu mengaktifkan siswa untuk belajar dan mampu mengondisikan siswa agar senang untuk belajar di dalam kelas. Karena belajar memang merupakan sustu prosess aktf dari siswa dalam membangu pengetahuannya, bukan proses pasif yang hanya menerima kucuran ceramah guru tentang pengetahuan. Jika suatu pembelajaran tidak memberikan kesempatan kepada siswa untuk berperan aktif, maka pembelajaran tersebut akan berentangan dengan hakekat belajar.

Salah satu alternatif untuk meningkatkan hasil belajar siswa adalah dengan menggunakan media atau alat peraga. Media alat peraga adalah media alat bantu pembelajaran, dan segala macam benda yang digunakan untuk memperagakan materi pelajaran. Alat peraga ialah alat-alat yang digunakan guru yang berfungsi membantu guru dalam proses mengajarrnya dan membantu peserta didik dalam proses belajarnya. Alat peraga yang peneliti pilih adalah media wayang. Media wayang merupakan sebuah media yang termasuk ke dalam jenis media visual yang berbentuk tiga dimensi, karena media ini dapat dilihat dan dipegang. Peran media wayang dalam pembelajaran ini sangat efektif dalam pembelajaran bahasa Indonesia dalam materi cerita rakyat terutama bagi siswa. Minat dan motivasi belajar siswa dapat ditumbuhkan dengan menggunakan media pembelajaran yang menarik karena siswa akan terfokus atau tertarik untuk mendengarkan apa yang di sampaikan oleh seorang guru dalam penyampain materi di dalam kelas.

Berdasarkan latar belakang di atas, peneliti tertarik melakukan penelitian tindakan kelas dengan judul "Meningkatkan Hasil Belajar Melalui Penerapan Media Wayang Pada Mata Pelajaran Bahasa Indonesia Kelas V Sekolah Dasar Islam Terpadu AD-DHUHA”.

\section{B. Identifikasi Masalah}

Berdasarkan latar belakang masalah yang ditemukan maka dapat di identifikasi beberapa masalah sebagai berikut : 
1. Hasil belajar siswa rendah.

2. Pendidik tidak menggunakan media yang tepat dalam pembelajaran.

3. Peserta didik cenderung kurang aktif dalam mendengarkan sebuah cetita yang sedang berlangsung diajarkan oleh seorang guru.

\section{Batasan Masalah}

Berdasarkan identifikasi masalah di atas, yang menjadi batasan pada penelitian ini adalah sebagai berikut:

Penelitian ini dilaksanakan untuk meningkatkan hasil belajar siswa pada ranah kognitif, Penelitian ini dilaksanakan di kelas V Sekolah Dasar Islam Terpadu Ad- Dhuha kecamatan pelepat ilir, dan Penelitian ini dilaksanakan pada mata pelajaran bahasa Indonesia materi cerita rakyat dengan menerapkan media wayang.

\section{D.Rumusan Masalah}

Berdasarkan latar belakang dan batasan pada penelitian diatas, permasalahan yang dapat dirumuskan adalah, sebagai berikut :

Apakah penerapan media wayang dapat meningkatkan hasil belajar siswa dalam materi cerita rakyat pada mata pelajran bahasa Indonesia di kelas V Sekolah Dasar Islam Terpadu Ad- Dhuha?

\section{Teori/Kajian}

\section{Hasil Belajar}

Hasil belajar adalah kemampuan-kemapuan yang dimiliki siswa setelah ia menerima pengalaman belajarnya. ${ }^{9}$ Sedangkan menurut Gagne Hasil belajar adalah terbentuknya konsep, yaitu kategori yang kita berikan pada stimulus yang ada di lingkungan, yang menyediakan skema yang terorganisasi untuk mengasimilasi stimulus-stimulus baru dan menentukan hubungan di dalam dan di antara kategori-kategori. ${ }^{10}$ Hasil belajar adalah perubahan perilaku secara keseluruhan bukan

${ }^{9}$ Nana Sudjana, Penilaian Hasil Proses Belajar Mengajar, (Bandung:PT. Remaja Rosdakarya,2009), hal. 22.

${ }^{10}$ Purwanto, Evaluasi Hasil Belajar, (Yogyakarta:Pustaka Pelajar,2016), hal. 42. 
hanya salah satu aspek potensi kemanusiaan saja, artinya hasil pembelajaran yang dikategorikan oleh para pakar pendidikan sebagaimana tersebut diatas tidak terlihat secara fragmentaris atau terpisah, melainkan komprehensif. ${ }^{11}$ Hasil belajar adalah pola-pola perbuatan, nilai-nilai, pengertian- pengertian, sikap-sikap, apresiasi dan keterampilan. ${ }^{12}$

Dari pendapat-pendapat diatas dapat dipahami bahwa yang dimaksud dengan hasil belajar adalah nilai atau keterampilan yang didapatkan oleh siswa dari proses belajarnya setelah pelaksanaan kegiatan pembelajaran.

\section{Indikator Hasil Belajar}

\begin{tabular}{|c|c|c|}
\hline $\begin{array}{l}\text { Ranah / Jenis } \\
\text { Prestasi }\end{array}$ & Indikator & Bentuk Kegiatan Siswa \\
\hline \multirow[t]{3}{*}{ Ranah (Kognitif) } & Pengetahuan & $\begin{array}{l}\text { Menghafal } \\
\text { Mengingat } \\
\text { Memilih } \\
\text { Mendefinisikan }\end{array}$ \\
\hline & Pemahaman & $\begin{array}{l}\text { Menerjemahkan. } \\
\text { Merubah. } \\
\text { Menguraikan dengan kata- } \\
\text { kata sendiri. }\end{array}$ \\
\hline & Aplikasi & $\begin{array}{l}\text { Menggunakan } \\
\text { Mengoperasikan } \\
\text { Menciptakan membuat } \\
\text { perubahan } \\
\text { Menyelesaikan } \\
\text { Memperhitungkan }\end{array}$ \\
\hline
\end{tabular}

${ }^{11}$ Agus Suprijono, Cooperatif Learning: Teori \& Aplikasi PAIKEM (Yogyakarta: Pustaka Pelajar, 2013), cet.10, hal. 7.

${ }^{12}$ Ibid., hal. 5. 


\begin{tabular}{|l|l|l|}
\hline Analisis & Membagi \\
& Menganalisis \\
& Membedakan \\
& Memisahkan \\
& Membagi \\
& Merinci \\
& Menganalisis \\
\hline \multirow{2}{*}{ Sintesis } & Merencanakan \\
& Menyusun \\
& Mengubah \\
& Mengatur \\
& Menyimpulkan \\
\hline \multirow{2}{*}{ Evaluasi } & Menilai \\
& Membenarkan \\
& Mengkritik \\
& Mengevaluasi \\
\hline
\end{tabular}

\section{Media Pembelajaran Wayang}

Media berasal dari bahasa latin medius yang secara harfiah berarti “ Tengah , perantara atau pengantar “. Menurut Gerlach \& Ely bahwa media apabila dipahami secara garis besar adalah manusia, materi, atau kejadian yang membanggun kondisi yang membuat siswa mampu memperoleh pengetahuan, ketersmpilan atau sikap. Secara garis khusus, pengertian media dalam proses belajar mengajar cenderung diartikan sebagai alat-alat grafis, photografis atau elektronis untuk menangkap, memproses dan menyusun kembali informasi visual atau verbal. ${ }^{13}$ Media merupakan wahana penyalur

${ }^{13}$ Azhar Arsyad, Media Pembelajaran (Jakarta: PT. Raja Grafindo, 2016), cet. 2. hal. 3. 
informasi belajar atau penyalur pesan. ${ }^{14}$ Berdasarkan uraian diatas dapat disimpulkan bahwa media merupakan alat yang di gunakan seorang pendidik dalam menyampaikan materi pembelajran kepada peserta didik untuk mencapai tujuan pembelajaran.

Sedangkan wayang adalah benda tiruan dari bentuk/ tokoh manusia atau binatang. Media wayang merupakan sebuah media yang termasuk ke dalam jenis media visual yang berbentuk tiga dimensi, yang dapat berupa gambar kartun atau gambar asli yang diberi tangkai untuk menggerak- gerakkannya.. Dalam pembelajaran bahasa Indonesia materi mengidentifikasi unsur cerita cara meragakan media ini guru bercerita dengan meragakan wayang yang sesuai dengan ceritanya. Jadi dalam hal ini, guru dituntut memerankan tokoh dalam cerita. ${ }^{15}$

\section{Pembelajaran Bahasa Indonedia}

Pendidikan Bahasa Indonesia merupakan salah satu aspek penting yang perlu diajarkan kepada para siswa di sekolah. Maka mata pelajaran ini kemudian diberikan sejak masih di bangku SD karena dari situ diharapkan siswa mampu menguasai,memahami dan dapat mengimplementasikan keterampilan berbahasa. Seperti membaca, menyimak, menulis, dan berbicara. Permendiknas No. 22 Tahun 2006, Bahasa memiliki peran sentral dalam perkembangan intelektual, sosial, dan emosional peserta didik dan merupakan penunjang keberhasilan dalam mempelajari semua bidang studi.Pembelajaran Bahasa Indonesia diarahkan untuk meningkatkan kemampuan peserta didik untuk berkomunikasi dalam bahasa indonesia dengan baik dan benar. Hal tersebut dapat terlihat dalam Standar Kompetensi (SK) mendengarkan, memahami penjelasan narasumber dan cerita rakyat secara lisan dsn Kompetensi Dasar (K.D) mengidentifikasi unsur cerita rakyat yang didengarnya.

14 Widiawati “Penggunaan Media Wayang Untuk Meningkatkan Keterampilan Menyimak Cerita Pendek”dalam jurnal BRILLIANT: Jurnal Riset dan Konseptual Volume 2 Nomor 1

${ }^{15}$ Ibid, hal. 44. 


\section{METOLOGI PENELITIAN}

Penelitian ini menggunakan pendekatan kualitatif yaitu penelitian yang bertujuan untuk menggambarkan keadan atau suatu penomena yang terjadi di Sekolah Dasar Islam Terpadu Ad-Dhuha di kelas V. Penelitian tindakan ini menggunakan analisa data deskriptif kuantitatif teknik persentase. Maka penelitian tindakan ini akan menganalisa data dengan jalan menganalisa meningkatkan minat membaca dengan media buku komik.

Teknik pengumpulan data yang dilakukan dalam penelitian ini, terdiri dari, observasi dan wawan cara dan dokumentasi.

Rumus Untuk menghitung ketuntasan adalah sebagai berikut :

$$
P=\underline{f} \times 100 \%
$$

Sumber : ( Arikunto, (2006:12)

Keterangan :

$\mathrm{P}=$ Persentase

$\mathrm{f}=$ frekuensi yang sedang dicari presentasinya

$\mathrm{N}=$ Jumlah frekuensi/banyaknya individu

\section{TEMUAN DAN HASIL PEMBAHASAN}

\section{HASIL PENELITIAN TINDAKAN SIKLUS 1}

Langkah awal dalam pelaksanaan prasiklus ini peneliti melakukan observasi pada hari senin 19 september 2020 di sekolah dasar islam terpadu ad- dhuha yang terletak di jalan asahan unit 1 dusun purwasari, kelas yang peneliti jadikan objek penelitian adalah kelas V (lima) dengan jumlah 23 orang siswa yang terdiri dari 8 lakilaki dan 15 siswa perempuan.

Analisi Evaluasi Hasil Belajar Siswa Sebelum Tindakan

\begin{tabular}{|l|l|l|l|l|}
\hline No & Nama Siswa & Kkm & Nilai & Keterangan \\
\hline 1. & Aura Putrid Salsabila & 75 & 70 & Tidak tuntas \\
\hline
\end{tabular}




\begin{tabular}{|c|c|c|c|c|}
\hline 2. & Aurel Tyas Maharani & 75 & 75 & Tuntas \\
\hline 3. & Dyah Hanna Azarin & 75 & 70 & Tidak tuntas \\
\hline 4. & Faiz Nur Irsyad & 75 & 80 & Tuntas \\
\hline 5. & Fajar Akhamaludin & 75 & 80 & Tuntas \\
\hline 6. & Fanny Adelia & 75 & 70 & Tidak tuntas \\
\hline 7. & Faqih Ardiansyah & 75 & 50 & Tidak tuntas \\
\hline 8. & Fathiya Mutia & 75 & 60 & Tidak tuntas \\
\hline 9. & Fazri Octaviando & 75 & 80 & Tuntas \\
\hline 10. & Gian Maulana Pratama & 75 & 75 & Tuntas \\
\hline 11. & Hanifa Salma & 75 & 85 & Tuntas \\
\hline 12. & Jihan Fadhillah & 75 & 60 & Tidak tuntas \\
\hline 13. & Khaisyah Putri & 75 & 80 & Tuntas \\
\hline 14. & Khilya Izzati & 75 & 70 & Tidak tuntas \\
\hline 15. & M. Robiul Amza & 75 & 50 & Tidak tuntas \\
\hline 16. & Lia Hidayati & 75 & 70 & Tidak tuntas \\
\hline 17. & Naisyah Putri Nurin & 75 & 55 & Tidak tuntas \\
\hline 18. & Naufal Nailil Abror & 75 & 85 & Tuntas \\
\hline 19. & Nuria Lutfiani & 75 & 70 & Tidak tuntas \\
\hline 20. & Olivia Yolanda & 75 & 80 & Tuntas \\
\hline 21. & Reza Ade & 75 & 70 & Tidak tuntas \\
\hline 22. & Riva Errisha & 75 & 65 & Tidak tuntas \\
\hline 23. & Sheiva Mulya Ika Putri & 75 & 75 & Tuntas \\
\hline
\end{tabular}

Berdasarkan tabel di atas terlihat bahwa 56,52\% atau 13 (tiga belas) orang siswa yang memperoleh nilai dibawah kriteria ketuntasan minimal (KKM) dengan mendapatkan nilai 50- 70 , sedangkan hanya 43,47\% dari 10 (Sepuluh) orang siswa yang memperoleh nilai di atas kriteria ketuntasan minimal (KKM) dengan mendapatkan nilai 75- 85 . Melihat hasil belajar siswa di atas maka peneliti berencana menerapkan Media Wayang dalam pembelajaran Bahasa Indonesia yang bertujuan meningkatkan hasil belajar siswa. Oleh sebab itu peneliti membuat kesepakatan dengan Wali Kelas V Sekolah Dasar Islam Terpadu Ad- Dhuha untuk menerapkan Media Wayang ketika 
melaksanakan pembelajaran Bahasa Indonesia pada materi cerita rakyat.

\section{Deskripsi Pelaksanaan Siklus Satu (I) Pertemuan 2}

Dalam prosedur pelaksanaan PTK ini di sekolah dasar islam terpadu ad- dhuha sesuai yang telah dikemukaan oleh Kemmis and Mc Tanggart kegiatan dalam melaksanakan setiap siklus terdiri dari beberapa tahapan, yaitu : perencanaan (plan), pelaksanaan dan pengamatan (act dan observer), refleksi (reflect), dan perencanaan ulang.

Interval nilai tes siklus I pertemuan II

\begin{tabular}{|l|l|l|l|}
\hline No & Interval Nilai & Jumlah Siswa & Ket \\
\hline 1 & $30-35$ & - & Dibawah KKM \\
\hline 2 & $40-45$ & 3 & Dibawah KKM \\
\hline 3 & $50-55$ & 4 & Dibawah KKM \\
\hline 4 & $60-65$ & 5 & Dibawah KKM \\
\hline 5 & $70-75$ & 6 & Diatas KKM \\
\hline 6 & $80-85$ & 3 & Diatas KKM \\
\hline 7 & $90-95$ & 2 & Diatas KKM \\
\hline 8 & 100 & - & Diatas KKM \\
\hline Jumlah & 23 & \\
\hline
\end{tabular}

Pada tes siklus 1 yang dilakukan oleh peneliti dapat diperoleh dari 23 jumlah siswa hanya 11 siswa dengan persentase 47,82\% yang tuntas, sedangkan 12 siswa dengan persentase 52,17\% belum untas. Hasil tes ini juga penting untuk melihat kemampuan siswa dalam menguasai konsep pembelajaran bahasa Indonesia pada materi cerita rakyat dengan menggunakan media wayang di kelas $\mathrm{V}$ sekolah dasar isalam terpadu ad-dhuha. Oleh karena itu dapat disimpulkan bahwa ketuntasan belajar siswa pada siklus 1 pertemuan 2 belum tuntas. 


\section{B. Hasil Penelitian Tindakan Siklus II}

\section{Deskripsi Pelaksanaan Siklus Satu (II) Pertemuan 1}

Dalam prosedur pelaksanaan PTK ini di sekolah dasar islam terpadu ad- dhuha sesuai yang telah dikemukaan oleh Kemmis and Mc Tanggart kegiatan dalam melaksanakan setiap siklus terdiri dari beberapa tahapan, yaitu : perencanaan (plan), pelaksanaan dan pengamatan (act dan observer), refleksi (reflect), dan perencanaan ulang. Refleksi kegiatan pembelajaran pada siklus dua dibagi menjadi dua siklus, dimana setiap 1 siklus terdiri dari 2 kali pertemuan.

Interval nilai tes siklus II Pertemuan I

\begin{tabular}{|l|l|l|l|}
\hline No & Interval Nilai & Jumlah Siswa & Ket \\
\hline 1 & $30-35$ & - & Dibawah KKM \\
\hline 2 & $40-45$ & - & Dibawah KKM \\
\hline 3 & $50-55$ & 3 & Dibawah KKM \\
\hline 4 & $60-65$ & 6 & Dibawah KKM \\
\hline 5 & $70-75$ & 7 & Diatas KKM \\
\hline 6 & $80-85$ & 4 & Diatas KKM \\
\hline 7 & $90-95$ & 3 & Diatas KKM \\
\hline 8 & 100 & - & Diatas KKM \\
\hline Jumlah & & 23 & \\
\hline
\end{tabular}

Pada tes siklus II yang dilakukan oleh peneliti dapat diperoleh dari 23 jumlah siswa hanya 14 siswa dengan persentase 52,17\% yang tuntas, sedangkan 9 siswa dengan persentase 39,13\% belum untas. Hasil tes ini juga penting untuk melihat kemampuan siswa dalam menguasai konsep pembelajaran bahasa Indonesia pada materi cerita rakyat dengan menggunakan media wayang di kelas $\mathrm{V}$ sekolah dasar isalam terpadu ad-dhuha. Oleh karena itu dapat disimpulkan bahwa ketuntasan belajar siswa pada siklus 2 pertemuan 1 belum tuntas. 


\section{Deskripsi Pelaksanaan Siklus Satu (II) Pertemuan 2}

Dalam prosedur pelaksanaan PTK ini di sekolah dasar islam terpadu ad- dhuha sesuai yang telah dikemukaan oleh Kemmis and Mc Tanggart kegiatan dalam melaksanakan setiap siklus terdiri dari beberapa tahapan, yaitu : perencanaan (plan), pelaksanaan dan pengamatan (act dan observer), refleksi (reflect), dan perencanaan ulang. Berikut merupakan penjabaran tindakan kelas siklus 2 pertemuan 2 :

\section{Interval nilai tes siklus II pertemuan II}

\begin{tabular}{|l|l|l|l|}
\hline No & Interval Nilai & Jumlah Siswa & Ket \\
\hline 1 & $30-35$ & - & Dibawah KKM \\
\hline 2 & $40-45$ & - & Dibawah KKM \\
\hline 3 & $50-55$ & - & Dibawah KKM \\
\hline 4 & $60-65$ & 4 & Dibawah KKM \\
\hline 5 & $70-75$ & 7 & Diatas KKM \\
\hline 6 & $80-85$ & 8 & Diatas KKM \\
\hline 7 & $90-95$ & 4 & Diatas KKM \\
\hline 8 & 100 & - & Diatas KKM \\
\hline Jumlah & 23 & \\
\hline
\end{tabular}

Pada tes siklus II pertemuan 2 yang dilakukan oleh peneliti dapat diperoleh dari 23 jumlah siswa terdapat 19 siswa dengan persentase $82,60 \%$ yang tuntas, sedangkan 4 siswa dengan persentase $17,39 \%$ belum tuntas. Hasil tes ini juga penting untuk melihat kemampuan siswa dalam menguasai konsep pembelajaran bahasa Indonesia pada materi cerita rakyat dengan menggunakan media wayang di kelas V sekolah dasar isalam terpadu ad-dhuha. Oleh karena itu dapat disimpulkan bahwa ketuntasan belajar siswa pada siklus II pertemuan 2 sudah tuntas.

\section{KESIMPULAN}

Penerapan dengan media wayang pada mata pelajaran bahasa Indonesia banyak mendapat keuntungan terutama bagi siswa. Sebelum diterapkan media pembelajaran ini hasil belajar siswa masih 
sangat rendah, selain itu banayak siswa yang kurang aktif dalam pembelajaran, hal ini disebabkan cara guru menerapkan pembelajaran dengan catra yang biasa-biasa saja, sehingga siswa kurang aktif dan kurang minat dalam mengikuti pembelajaran.

Maka dari itu peneliti menerapkan media wayang ini pada mata pelajaran bahasa Indonesia dengan tujuan untuk meningkatkan hasil belajar siswa, dan yang terjadi pada siklus II siswa sudah berani menjawab pertanyaan, bekerjasama dan mampu bersaing antar kelompok. Dari kegiatan kerja kelompok yang dilaksanakan siswa minat belejar semakin tinggi sehinggai hasil belajar siswa sangat meningkat. Setelah selesai persiklus peneliti memberikan tes kepada siswa untuk mengetahui keberhasilan siswa dalam memahami materi yang telah disampaikan.

\section{Daftar Pustaka}

Abu Ahmadi Dan Joko. 2005. Strategi Belajar Mengajar. Bandung: CV Pustaka Setia.

Arsyad, Azhar. 2016. Media Pembelajaran. Jakarta: PT. Raja Grafindo.

Faizun. 2012. Kurikulum Bahan Perkuliah Prodi Stkip Jombang. Jombang: STKIP.

Kenastiti, Putri. 2016. Pengembangan Media Pembelajaran Wayang Todong Untuk Meningkatkan Keterampilan Mendengarkan Pada Mata Pelajaran Bahasa Indonesia Kelas Ii Sd 2 Pedes Argomulyo Sedayu Bantul Tahun Ajaran 2015/2016. Yogyakarta: UNIVERSITAS PGRI YOGYAKARTA.

Ngadino. 2009. Pengembangan Media Pembelajaran, Surakarta: Pendidikan Profesi Guru FKIP UNS.

Novita Mona. 2018. PTK Tidak Horor. Surabaya: CV.Pustaka Media Guru. 
Pemerintah Indonesia.2003. Undang -Undang Nomor 20 Tahun 2003 tentang Sistem Pendidikan Nasional. Lembaran Negara RI Tahun 2003 Jakarta : Sekretariat Negara.

Purwanto. 2016. Evaluasi Hasil Belajar. Yogyakarta: Pustaka Pelajar.

Ridwan A.S dan sudirman. 2017. Penelitian Tindakan Kelas Pengembangan Profesi Guru. Tanggerang; Tira Smart.

Salamah Evi Rizqi. 2017. Penggunaan Media Wayang Pada Pembelajaran Ips Materi Tokoh Tokoh Kemerdekaan Indonesia Untuk Meningkatkan Hasil Belajar Siswa Kelas V Sekolah Dasar , dalam jurnal PENDIDIKAN KE-SD-AN Vol 12, No 2.

Sudjana, Nana. 2009. Penilaian Hasil Proses Belajar Mengajar,Bandung: PT. Remaja Rosdakarya.

Suprijono, Agus. 2013. Cooperatif Learning: Teori \& Aplikasi PAIKEM . Yogyakarta: Pustaka Pelajar.

Syah, Muhibbin. 2009. Psikologi Belajar. Jakarta: Rajawali Pers.

Widiastuti. 2017. Penggunaan Media Wayang untuk Meningkatkan Keterampilan Menyimak Cerita Pendek" dalam jurnal Riset dan Konseptual Volume 2 Nomor 1.

Widiawati. 2017 . Penggunaan Media Wayang Untuk Meningkatkan Keterampilan Menyimak Cerita Pendek, dalam jurnal BRILLIANT: Jurnal Riset dan Konseptual Volume 2 Nomor 1.

Zain, Djamarah. 2013. Strategi Belajar Mengajar. Jakarta: Rineka Cipta.

Zainal Aqib DKK. 2017. Penelitian Tindakan Kelas SD/MI. Yogyakarta: Ar-Ruzz Media. 